\title{
Implementasi Kebijakan Perlindungan Perempuan Korban Kekerasan dalam rumah tangga (Studi Pada Pusat Pelayanan Terpadu Perempuan Dan Anak Korban Kekerasan Rekso Dyah Utami)
}

\author{
Okti Inayatur Rohmah ${ }^{1}$
}

\author{
1Universitas Islam Negeri Sunan Kalijaga, Yogyakarta, Indonesia \\ *Korespondensi: Oktiinayatur14@gmail.com
}

\begin{abstract}
Abstrak: Di masa pandemi ini, kasus-kasus kekerasan terhadap perempuan dan anak terus meningkat. Kekerasan dalam rumah tangga adalah setiap perbuatan terhadap seseorang terutama perempuan yang berakibat timbulnya kesengsaraan atau penderitaan secara fisik, seksual, psikologis, dan/atau penelantaran rumah tangga termasuk ancaman untuk melakukan perbuatan yang memaksa atau perampasan kemerdekaan secara mekawan hukum dalam lingkup rumah tangga. Penelitian ini bertujuan untuk mendeskripsikan Implementasi Kebijakan Perlindungan Perempuan Korban Kekerasan dalam rumah tangga (Studi Pada Pusat Pelayanan Terpadu Perempuan Dan Anak Korban Kekerasan Rekso Dyah Utami). Implenetasi kebijakan ini merupakan salah satu upaya dalam menangani kasus kekerasan terhadap perempuan yang semakin meningkat. Data yang didapatkan dalam penelitian ini melalui wawancara dengan pekerja sosial di lembaga tersebut. hasil penelitian menunjukan bahwa Implementasi kebijakan program yang dilaksanakan oleh Dinas Pemberdayaan perempuan dan perlindungan anak bersama dengan unit pelaksana teknis yaitu P2TPAKK Rekso Dyah Utami program perlindungan terdiri dari yaitu dari lima program yaitu 1) Program pencegahan kekekerasan, 2) Program Pelayanan pos pengaduan, konsultasi dan pendampingan, 3) Program Konseling dalam bidang kesehatan, psikologi, hukum, sosial dan kerukunan rumah tangga , 4) Program Layanan bantuan hukum, program rujukan, dan 5) Program Semi shelter, shelter dan pasca shelter. Penyelenggaraan program perlindungan sudah mencapai hasil yang cukup maksimal.
\end{abstract}

Kata-kata kunci: implementasi, kekerasan, perempuan.

Abstract: During this pandemic, cases of violence against women and children continue to increase. Domestic violence is any act against a person, especially a woman, that results in physical, sexual, psychological misery or suffering, and/or neglect of the household, including threats to commit acts of coercion or deprivation of liberty legally within the scope of the household. This study aims to describe the implementation of policies to protect women victims of domestic violence (Studies at the Integrated Service Center for Women and Children Victims of Violence Rekso Dyah Utami). The implementation of 
this policy is one of the efforts to deal with the increasing cases of violence against women. The data obtained in this study through interviews with social workers at the institution. The results showed that the implementation of program policies carried out by the Office of Women's Empowerment and Child Protection together with the technical implementing unit, namely P2TPAKK Rekso Dyah Utami, the protection program consisted of five programs, namely 1) Violence prevention program, 2) Postal service program for complaints, consultations and assistance, 3) Counseling Programs in the fields of health, psychology, law, social and household harmony, 4) Legal aid service programs, referral programs, and 5) Semi-shelter, shelter and post-shelter programs. The implementation of the protection program has achieved maximum results.

Keywords: implementation, violence, women.

\section{Pendahuluan}

Pandemi covid 19 atau virus corona yang hingga kini masih merebak, telah memberikan dampak buruk hampir diseluruh aspek kehidupan manusia. Aspek ekonomi dan sosial menjadi salah satu aspek yang paling terdampak akibat pandemi ini. pandemi covid 19 telah meningkatkan salah satu persoalan sosial yakni kekerasan terhadap perempuan. (kompas, 2021).

Tindak kekerasan terhadap perempuan khususnya yang ada di Indonesia bukanlah terjadi sebab tunggal. Faktor sejarah dan budaya patriarki yang tumbuh dalam sosial masyarakat adalah sebab mendasar dari terjadinya diskriminasi antara perempuan dengan laki-laki. Faktor agama dan faktor ekonomi juga menjadi salah satu faktor yang memperkuat kedudukan laki-laki. Bentuk kekerasan terhadap perempuan yang juga dapat dikategorikan sebagai kejahatan seksual atau gender based violonce adalah kekerasan yang terjadi dalam rumah tangga atau yang biasa dikenal dengan istilah domestic violence. (Dadang, 1997) Kekerasan dalam rumah tangga (KDRT) menurut pasal 1 butir UU No.23 Tahun 2004 adalah setiap perbuatan terhadap seseorang terutama perempuan yang berakibat timbulnya kesengsaraan atau penderitaan secara fisik, seksual, psikologis, dan/atau penelantaran rumah tangga termasuk ancaman untuk melakukan perbuatan yang memaksa atau perampasan kemerdekaan secara mekawan hukum dalam lingkup rumah tangga. (UU No. $23,2002)$.

Sedangkan PBB mendefenisikan istilah kekerasan terhadap perempuan pada deklarasi tahun 1993 sebagai semua tindakan kekerasan berdasarkan 
gender (maksudnya atas dasar pertimbangan gender) yang mengakibatkan kerugian/bahaya/melukai secara fisik, sexual, psikologi maupun penderitaan terhadap perempuan, termasuk pula tindakan mengancam kekerasan, perampasan secara sewenang-wenang terhadap kebebasan, baik pada ranah publik maupun kehidupn pribadi. (Susi Deimiati, 2016).

Di masa pandemi ini, kasus-kasus kekerasan terhadap perempuan dan anak terus meningkat. Berdasarkan catatan tahunan komnas perempuan 2020, lebih dari sepertiga dari Lembaga layanan bagi perempuan korban kekerasan menyatakan bahwa laporan yang mereka terima di masa pandemic meningkat. Dalam catatan tahunan komnas perempuan, wilayah Jakarta mencattakan kasus terbanyak yaitu sebanyak 2.471 kasus yang ditangani oleh 9 lembaga, atau rata-rata setiap Lembaga menangani sebanyak 273 kasus. Ini artinya naik hamper 60\% dari rata-rata kasus yang ditangani oleh Lembaga pendampingan di Jakarta pada tahun sebelumnya. Serupa dengan ini pengaduan langsung ke komnas perempuan pada tahun 2020 naik hingga hamper 70\% yaitu mencapai 2.389 kasus. Komnas perempuan memprediksikan pengaduan kasus akan bertambah signifikan, mengingat hingga awal Mei saja komnas perempuan telah menerima lebih dari 1.200 kasus pengaduan langsung. (Komnas Perempuan, 2020).

Temuan kasus kekerasan dalam rumah tangga di Yogyakarta selama dua tahun terakhir juga mengalami kenaikan, kepala dinas pemberdayaan perempuan perlindungan anak menyatakan bahwa hal itu disebabkan oleh semakin aktifnya satuan tugas siap gerak anti kekerasan dalam melaksanakan tugas. Pada tahun 2019 terdapat 139 kasus kekerasan dalam rumah tangga (KDRT) di kota Yogyakarta dan jumlahnya meningkat menjadi 145 kasus pada 2020, dengan 39 kasus diantaranya menimpa anak. Pada Mei 2021 kepala dinas pemberdayaan perempuan perlindungan anak juga menyatakan bahwa ada peningkatan kasus daripada bulan sebelumnya. Menurutnya terdapat tiga faktor utama yang menjadi penyebab terjadinya kekerasan yaitu karakter pelaku, faktor ekonomi, dan orang lain. (Repjogja.republika.co.id, 2021). 
Hal ini sejalan dengan pernyataan Sutiwati dan Fadhilah dalam jurnal yang berjudul "Penanggulangan Tindak Pidana Kekerasan Dalam Rumah Tangga Di Kota Makassar". Dalam jurnal tersebut dijelaskan bahwa kekerasan terhadap perempuan juga merupakan fenomena sosial yang pada saat ini menjadi keprihatinan berbagai pihak. Dalam perkembangannya, korban kekerasan dalam rumah tangga sulit mengadukan penderitaan yang dialaminya kepada penegak hukum, karena kuatnya pandangan bahwa perlakuan kasar suami terhadap istri merupakan bagian dari peristiwa privat (urusan rumah tangga). (Sutiawati, Nur Fadhilah, 2020).

Tindakan Islam dalam mengubah cara pandang dan cara bersikap masyarakat arab pada perempuan terbilang radikal. Pemberdayaan perempuan menjadi salah satu topik yang sangat menonjol dalam Al-Qur'an. Perempuan bahkan diabadikan sebagai salah satu nama surat keempat yaitu an-nisa. Yusuf Al-Qardawi juga mengatakan bahwa dinatara topik terpenting yang dibawa AlQur'an, berkaitan dengan perkawinan adalah perintah untuk berlaku adil pada perempuan, membebaskannya dari kezaliman jahiliyyah, dan dari tindakan otoriter suami dalam menentukan kehidupannya. Al-Qur'an memberikan kehormatan pada perempuan baik sebagai anak, isteri, ibu maupun sebagai anggota masyarakat. (Nur Rofiah, 2017).

Melihat pada kenyataan tingginya kasus yang ada tentu hal ini menjadi tanggung jawab pemerintah dan masyarakat, hal ini sebagaimana diatur dalam peraturan daerah tentang perlindungan perempuan dan anak dari tindak kekerasan yang menjelaskan bahwa kewajiban dan tanggungjawab dalam memberikan perlindungan terhadap perempuan dan anak dari tindak kekerasan merupakan tanggung jawab Bersama. Upaya yang dilakukan oleh pemerintah kota Yogyakarta salah satunya melalui Pusat Pelayanan Terpadu Perempuan Dan Anak Korban Kekerasan Rekso Dyah Utami yang dibantu dengan unit-unit pelaksana teknis sebagai bentuk komitnen pemerintah kota Yogyakarta dalam melayani masyarakat, menjamin hak-hak masyarakat, dan memenuhi tanggungjawabnya terhadap masyarakat dengan menguatamakan 
kepentingan masyarakat, dimana dalam hal ini perempuan yang menjadi korban kekerasan.

\section{Metode Penelitian}

Penelitian yang digunakan adalah penelitian kualitatif. Menurut Sugino (2018) metode penelitian kualitatif adalah metode penelitian yang berlandaskan pada filsafat, yang digunakan untuk meneliti pada kondisi ilmiah (eksperimen) dimana peneliti sebagai intsrumen, tehnik pengumpulan data dan dianalisis yang bersifat kualitatif yang lebih menekankan pada makna. Metode penelitian kualitatif bertujuan untuk menganalisa dan mendeskripsikan fenomena atau obyek penelitian melalui aktivitas sosial, sikap dan persepsi orang baik secara individu ataupun kelompok. Dalam hal ini penulis menggunakan studi kepustakaan dengan mencari data lewat berbagai dkumen, ataupun melalui media online.

\section{Hasil dan Pembahasan}

\section{Pengertian implementasi kebijakan}

Implementasi kebijakan adalah hal yang terpenting pada kebijakan. Pada tahap ini menentukan apakah kebijakan yang ditempuh pemerintah benarbenar diterima di lapangan dan berhasil guna menghasilkan output dan outcomes seperti yang direncanakan. ( Dila, Karjuni, 2020).

Solichin mengutip pada kamus Webster berkenaan dengan pengertian impelementasi yang dirumuskan pendek bahwa to implement (mengimplementasikan) berarti to provide means for carrying out (menyediakan sarana untuk melaksanakan sesuatu) to give practical effect to (menimbulkan dampak/akibat terhadap sesuatu). Dari definisi tersebut maka implementasi pelaksanaan dapat diartikan sebagai suatu proses dalam melaksanakan keputusan pelaksanaan peradilan, perintah, presiden atau dekrit presiden. (Abdul, 2004). 
Van Meter dan van Horn dalam Winarno mendefinisikan implmentasi kebijakan sebagai berikut: policy implementation encompasses those actions by public and private individuals (and groups) that are directed at the achivement of goals and objectives set forth in prior policy desicions. Definisi tersebut memiliki makna bahwa implementasi kebijakan sebagai tindakan-tindakan yang dilakukan oleh individu-indvidu (atau kelompok-kelompok) pemerintah maupun swasta yang diarahkan untuk mencapai tujuan-tujuan yang telah ditetapkan dalam keputusan-keputusan kebijakan sebelumnya. (Budi, 2010).

Tindakan-tindakan tersebut meliputi usaha-usaha untuk mengubah keputusan-keputusan menjadi tindakan operasional dalam kurun waktu tertenu maupun dalam rangka melanjutkan usaha-usaha untuk mencapai perubahan-perubahan baik besar maupun kecil yang ditetatpkan oleh keputusan-keputusan kebijakan. Dalam hal ini yang perlu ditekankan adalah bahwa tahap implementasi kebijakan tidak akan dimulai sebelum tujuan-tujuan dan saran ditetapkan atau telah diidentifikasi oleh keputusan-keputusan kebijakan. Dengan demikian, tahap implementasi terjadi hanya setelah undangundang ditetatpkan dan dana disediakan untuk membiayai implementasi kebijakan tersebut.

Selanjutnya Mazmanian dan Sabatier dalam Wahab mendefinisikan implementasi kebijakan sebagai memahami apa yang senyatanya terjadi ssesudah program dinyatakan berlaku atau dirumuskan. Fokus implementasi kebijakan, yaitu pada kejadian-kejadian atau kegiatan yang timbul setelah disahkannya pedoman-pedoman kebijakan negara, yaitu mencakup usahausaha untuk mengadministrasikannya maupun untuk menimbulkan akibat atau dampak nyata pada masyarakat atau kejadian-kejadian. ( Solichin, 2011).

Implementasi kebijakan berkaitan dengan proses dimana setelah masalah publik masuk dalam agenda kebijakan maka berbagai opsi dirancang untuk mengatasinya. Selanjutnya pemerintah membuat beberapa pilihan kebijakan dan menerapkan kebijakan tersebut. Beberapa cara untuk mengimplementasikan adalah dengan proses top-down yaitu proses yang 
menekankan bagaimana mengimplementasikan kebijakan secara efektif dari pembuat kebijakan ke sasaran. Cara kedua yaitu menggunakan pendekatan button-up yaitu implementasi kebijakan berdasarkan perspektif sasaran kebijakan.

Sementara Nugroho menyatakan implementasi kebijakan pada prinsipnya adalah cara agar sebuah kebijakan dapat mencapai tujuannya. Untuk mengimplementasikan kebijakan publik, ada dua pilihan langkah yang dilakukan yaitu:

1. Langsung mengimplementasikan dalam bentuk program-program.

2. Melalui formulasi kebijakan derivat atau turunan dari kebijakan publik tersebut. Kedua pilihan langkah tersebut membutuhkan cara yang lebih sistematis untuk memahami. (Ryan, 2003).

Menurut Riant Nugroho hal penting yang harus diperhatikan dalam proses implementasi kebijakan yaitu mengenai prinsip-prinsip dasar bagi implementasi kebijakan yang efektif yaitu: 1) ketepatan kebijakan 2) ketepatan pelaksanaan 3) ketepatan target 4) ketepatan lingkungan 5) ketepatan proses.

\section{Pengertian Kekerasan Dalam Rumah Tangga}

\section{kekerasan dalam rumah tangga}

Kekerasan dalam rumah tangga merupakan salah satu dari berbagai macam tindak pidana yang telah teridentifikasi di dalam masyarakat. Kekerasan dalam rumah tangga yang sering terjadi adalah kekerasan terhadap istri. Kekerasan yang terjadi dalam rumah tangga khususnya istri sering didapati, bahkan tidak sedikit jumlahnya.

Pengertian kekerasan dalam rumah tangga diatur dalam pasal 1 ayat (1) UU RI No. 23 tahun 2004 tentang penghapusan kekerasan dalam rumah tangga menyatakan bahwa:

"kekerasan dalam rumah tangga adalah setiap perbuatan terhadap seseorang terutama perempuan yang berakibat timbulnya kesengsaraan atau penderitaan secara fisik, 
seksual, psikologis, dan/atau penelantaran rumah tangga termasuk ancaman melakukan perbuatan, pemaksaan atau perampasan kemerdekaan secara melawan hukum dalam lingkup rumah tangga" (Mohmammad, 2013)

Selain di atas Elih N. Hasbianto memberikan pendefinisian kekerasan dalam rumah tangga sebagai suatu bentuk penganiayaan secara fisik maupun emosional/psikologis yang merupakan suatu cara spengontrolan terhadap pasangan dalam kehidupan keluarga. Dari pengertian di atas dapat disimpulkan bahwa kekerasan dalam rumah tangga adalah kekerasan secara fisik yang dilakukan suami yang berakibat kesengsaraan dan penderitaan secara fisik, seksual, psikologis terhadap istri.

\section{Jenis kekerasan dalam rumah tangga}

Adapun jenis kekerasan dalam rumah tangga menurut pasal 5 UU No.23 tahun 2004 meliputi kekerasan ekonomi, fisik, psikologis dan seksual.

1. Kekerasan ekonomi adalah tiap-tiap perbuatan yang membatasi istri untuk bekerja di dalam atau di luar rumah yang menghasilkan uang atau barang dan atau membiarkan istri bekerja untuk diekploitasi atau menelantarkan anggota keluarga dalam arti tidak memenuhi kebutuhan ekonomi keluarga.

2. Kekerasan fisik adalah setiap perbuatan yang menyebabkan rasa sakit, cedera, luka atau cacat pada tubuh seseorang dan atau menyebabkan kematian.

3. Kekerasan psikologis/psikis adalah setiap perbuatan dan ucapan yang mengakibatkan hilangnya rasa percaya diri, hilangnya kemampuan untuk bertindak dan rasa tidak berdaya serta rasa ketakutan pada si istri.

4. Kekerasan seksual adalah tiap-tiap perbuatan yang mencakup pelcehan seksual, memaksa istri baik secara fisik untuk melakukan hubungan seksual dan atau melakukan hubungan seksual tanpa persetujuan dan disaat istri tidak menghendaki, melakukan hubungan seksual dengan cara yang tidak eajar atau tidal disukai istri, maupun menjauhkan atau tidak memenuhi kebutuhan seksual istri. (Fathul, 2001). 


\section{Faktor terjadinya tindak kekerasan dalam rumah tangga}

Menurut Strauus A. Murray faktor yang memungkinkan terjadinya kekerasan dalam rumah tangga adalah sebagai berikut:

1. Pembelaan atas kekuasaan laki-laki

Laki-laki dianggap sebagai superioritas sumber daya dibandingkan dengan wanita, sehingga mampu mengatur dan mengendalikan wanita.

2. Diskriminasi dan pembatasan di bidang ekonomi

Diskriminasi dan pembatasan kesempatan bagi wanita untuk bekerja mengakibatkan wanita (istri) ketergantungan terhadap suami, dan Ketika suami kehilangan pekerjaan maka istri mendapatkan tindak kekerasan.

3. Beban pengasuhan anak

Istri yang bekerja menjadikannya menanggung beban sebagai pengasuh anak. Ketika terjadi hal yang tidak diharapkan terhadap anak, maka suami menyalahkan istri sehingga terjadi kekerasan dalam rumah tangga,

4. Wanita sebagai anak-anak

Konsep wanita sebagai hak milik bagi laki-laki menurut hukum, mengakibatkan keluasaan laki-laki untuk mengatur dan mengendalikan segala hak dan kewajiban wanita. Laki-laki merasa punya hak untuk melakukan kekerasan sebagai seorang bapak melakukan terhadap anaknya agar menjadi tertib.

5. Orientasi peradilan pidana bagi laki-laki

Posisi wanita sebagai istri di dalam rumah tangga yang mengalami kekerasan oleh suaminya, diterima sebagai pelanggaran hukum, sehingga penyelesaian kasusnya sering ditunda atau ditutup. Alasan yang lazim dikemukakan oleh penegak hukum yaitu adanya legimitasi hukum bagi suami melakukan kekerasan sepanjang bertindak dalam konteks harmoni keluarga. (Mohammad, 2013).

Implementasi pelaksanaan program perlindungan anak dan perempuan korban tindak kekerasan di kota Yogyakarta merupakan suatu proses pelaksanaan kegiatan yang dilakukan dengan melihat indikator yang terdapat 
dalam kebijakan tersebut. Pelaksanaan Kebijakan tersebut menunjukan peningkatakan yang signifikan artinya dalam proses penanganan anak dan perempuan korban kekerasan memperlihatkan hasil dan dampak yang cukup maksimal.

Hal ini bisa dilihat salah satunya dari peningkatan laporan oleh korban kekerasan dalam rumah tangga apalagi sejak pandemi covid 19 yang sebelumnya tidak mempunyai keberanian untuk melapor.

Adapun peningkatan jumlah kekerasan terhadap anak dan perempuan di kota Yogyakarta ini disebabkan oleh beberapa faktor. Faktor tersebut dapat berupa faktor ekonomi, faktor pendidikan, faktor psikologis dan faktor sosiologis masyarakat. Melihat jumlah kekerasan terhadap anak dan perempuan yang terus mengalami peningkatan yang signifikan maka pemerintah daerah kota yogyakarta memberlakukan peraturan daerah kota yogyakarta nomor 01 tahun 2012 tentang perlindungan perempuan dan anak dari tindakan kekerasan. Upaya penanganan pemerintah tersebut telah menghasilkan dampak yang cukup baik terutama pada korban kekerasan.

Dalam upaya pencegahan dan penanganan tindakan kekerasan yang terjadi pada anak dan perempuan pemerintah kota Yogyakarta dibantu oleh unit pelaksana teknis melakukan berbagai upaya. Adapun upaya yang dilakukan yaitu dengan adanya layanan pengaduan bagi korban kekerasan, pelayanan medis, pelayanan psikologis, penegakan dan bantuan hukum dan rehabilitasi sosial. Layanan tersebut dilaksanakan melalui kerja sama dengan beberapa instansi. Dimana pelayanan tersebut dilaksanakan sesuai dengan kebutuhan korban dan tidak dilaksanakan secara keseluruhan melihat kebutuhan korban yang berbeda-beda.

Penyelenggaraan perlindungan anak dan perempuan di kota yogyakarta terdiri dari lima bagian yaitu 1) Program pencegahan kekekerasan, 2) Program Pelayanan pos pengaduan, konsultasi dan pendampingan, 3) Program Konseling dalam bidang kesehatan, psikologi, hukum, sosial dan kerukunan rumah tangga ,4) Program Layanan bantuan hukum, program rujukan, dan 5) 
Program Semi shelter, shelter dan pasca shelter. Adapun pelaksanaan dari progra-program tersebut dijelaskan sebagai berikut :

Program pencegahan kekekerasan yaitu dengan Mensosialisasikan berbagai informasi dan peraturan yang berguna bagi peningkatan dan pemahaman, solidaritas dan kemampuan untuk mencegah terjadinya kekerasan terhadap perempuan dan anak. P2TPAKK Rekso Dyah Utami melakukan sosialisasi berupa pencegahan tindak kekerasan yang terjadi di masyarakat. Rekso Dyah Utami berperan sebagai wadah dalam rangka meningkatkan kemampuan masyarakat untuk memahami berbagai tindak kekerasan yang terjadi di masyarakat khususnya pada perempuan dan anak.

Program Pelayanan pos pengaduan, konsultasi dan pendampingan bagi korban keke rasan perempuan dan anak selama 24 jam. P2TPAKK Rekso Dyah Utami memberikan pelayanan terbaik dengan menyediakan layanan responsif 24 jam dalam menangani tindak kekerasan yang terjadi. Layanan tersebut dilakukan secara offline pada jam kerja serta online melalui media komunikasi berupa telepon, email dan lain-lain.

Program Konseling bidang kesehatan, psikologi, hukum, sosial dan kerukunan rumah tangga. Korban kekerasan yang telah melaporkan kejadian yang dialaminya akan mendapatkan pelayanan kesehatan bila memiliki luka fisik, lebam, luka bakar, luka akibat benda tajam dan apabila diperlukan korban akan mendapatkan pelayanan psikologis. Layanan psikologis yang dimaksud berupa terapi pemulihan luka psikis pada korban yang dilakukan oleh konselor di P2TPAKK Rekso Dyah Utami.

Program Layanan bantuan hukum. Program layanan hukum juga diberikan pada korban yang memerlukan bantuan terkait pendampingan dalam proses hukum, pendampingan kebutuhan korban seperti mendaftarkan kasus, mengumpulkan bukti-bukti, serta pendampingan dalam persidangan. Layanan sosial dan kerukunan rumah tangga yang diberikan P2TPAKK Rekso Dyah Utami berupa penanganan terhadap klien dalam pemulihan kehidupan yang terkait dengan kegiatan-kegiatan sosial dan hal-hal yang berkaitan dengan keharmonisan dan kerukunan rumah tangga. 
Program Rujukan. Program Rujukan dilakukan ketika P2TPAKK Rekso Dyah Utami memerlukan upaya penyembuhan dengan fasilitas yang lebih memadai seperti P2TPAKK Rekso Dyah Utami melakukan MOU dengan beberapa Rumah Sakit dalam menangani korban yang terkena luka pisik sehingga pelayanan dapat berjalan secara optimal.

Program Semi shelter, shelter dan pasca shelter. P2TPAKK Rekso Dyah Utami memiliki ruangan khusus sebagai rumah singgah dan rumah aman yang digunakan untuk melindungi korban dari pelaku selama proses pelayanan berlangsung. Rumah tersebut sangat dirahasiakan keberadaannya dengan alasan menjaga privasi korban dan melindungi korban dari ancaman pelaku kekerasan.

Dalam implementasinya apabila dilihat dari dari ketepatan program, ketepatan pelaksanaanm ketepatan target, ketepatan lingkungan dan ketepatan proses P2TPAKK Rekso Dyah Utami sudah sesuai dengan peraturan yang ditetapan oleh pemerintah kota Yogyakarta. Berikut penjelasannya:

Pertama, jika dilihat dari ketepatan program P2TPAKK Rekso Dyah Utami sudah mampu menjawab permasalahan banyaknya kasus kekerasan terhadap anak dan perempuan di kota Yogyakarta. Sebelum adanya program ini para korban kekerasan baik anak atau perempuan kebanyakan dari mereka tidak punya keberanian untuk melaporkan kasusnya. Hal ini disebabkan karena kesulitan akses, rasa bingung, dan minimnya pengetahuan korban tentang bantuan atau lembaga yang bisa membantu kasus kekerasan yang dialami. Adanya P2TPAKK Rekso Dyah Utami mampu meningkatkan jumlah pelaporan kasus. Peningkatan jumlah pelaporan kasus ini membuat korban kekerasan yang lain berani untuk menuntut hak-haknya dengan dibantu oleh P2TPAKK Rekso Dyah Utami. Ketika korban kekerasan baik anak atau perempuan melaporkan kasus yang menimpanya maka dari pihak P2TPAKK Rekso Dyah Utami berusaha memberikan pelayanan yang terbaik dengan memfasilitasi untuk berkonsultasi dengan para ahlinya seperti konselor, psikolog maupun dengan pekerja sosial. 
Kedua, dilihat dari ketepatan pelaksanaan. Dalam hal pelaksanaan P2TPAKK Rekso Dyah Utami, lembaga atau instansi yang ditunjuk sebagai implementor sudah tepat. Adapun lembaga implementor yang dimaksud adalah aparat penegak hukum, akademisi, institusi pemberi layanan kesehatan, maupun psikolog.

Ketiga dilihat dari ketepatan program. Dalam hal ini unit pelaksana teknis P2TPAKK Rekso Dyah Utami sudah memenuhi syarat ketetapan target, yaitu sesuai dengan target atau sasaran. Kemudian ketika program akan diimplementasikan target atau sasaran sudah bersedia untuk diintervensi artinya tidak ada paksaan apapun. Adapun target atau sasaran di P2TPAKK Rekso Dyah Utami adalah anak dan perempuan korban kekerasan yang benarbenar membutuhkan bantuan dari P2TPAKK Rekso Dyah Utami. Sebelum korban kekerasan mengenal adannya P2TPAKK Rekso Dyah Utami atau lembaga yang menangani korban kekerasan, korban cenderung mengalami kebingungan dan kesulitan ketika hendak melaporkan kasus yang dialami.

Keempat, dilihat dari ketepatan lingkungan. Adapun untuk lingkungan endogen, ineterkasi antara lembaga yang menaungi P2TPAKK Rekso Dyah Utami yaitu Dinas Pemberdayaan dan Perlindungan kota Yogyakarta. Kemudian untuk lingkungan eksogen sendiri masyarakat dan publik menerima dengan sangat bahagia dengan adanya P2TPAKK Rekso Dyah Utami karena dinilai sangat membantu korban yang mengalami kekerasan baik itu korban kekerasan terhadap anak maupun perempuan. Selain itu masyarakat juga sangat diperlukan dalam upaya pencegahan dan penanganan terhadap korban kekerasan. Hal ini terlihat dari dilibatkannya masyarakat dalam program pencegahan sebagai upaya untuk mengurangi angka kekerasan yang banyak terjadi di masyarakat terutama dalam rumah tangga.

Kelima, dilihat dari ketepatan proses. Secara umum implementasi program publik terdiri dari tiga proses yaitu (1) Policy Acceptance (2) Policy Adoption (3) strategic Readiness. Berakitan engan Poliy Axxeptance menurut implementor program ini penting untuk masa depan, yaitu untuk mengurangi tindak kekerasan terhadap anak dan perempuan terutama di masa pandemi 
covid 19 yang terus mengalami peningkatan. Dalam hal ini maka seluruh anggota dan elemen pemberdayaan perempuan dan perlindungan anak kota Yogyakarta bersama P2TPAKK Rekso Dyah Utami diharapkan memiliki komitmen yang tinggi pada isu gender agar implementasi proogram pelaksanaan dapat berjalan dengan efektif. Selanjutnya berkaitan dengan policy adoption, implementor menerima program karena adanya P2TPAKK Rekso Dyah Utami. Dalam melaksanakan tugas dan kewajibannya implementor bertugas untuk melaporkan hasilnya. Kemudian mengenai strategic readiness, implementor siap dalam melaksanakan program. Dalam hal ini Dinas pemberdayaan perempuan dan perlindungan anak kota Yogyakarta bekerja sama dengan P2TPAKK Rekso Dyah Utami siap melaksanakan program yang sudah ditetatpkan dalam upaya penanganan tindak kekerasan.

Dalam melaksanakan upaya pencegahan dan penanganan tindak kekerasan terhadap anak dan perempuan P2TPAKK Rekso Dyah Utami tentunya mengalami beberapa kendala dalam proses pelaksaan program tersebut sehingga hasilnya belum cukup memuaskan walaupun sudah menunjukan hasil yang signifikan. Dalam proses pelaksanaan program masih terhambat oleh beberapa hal seperti kurangnya komitmen dan komunikasi antar anggota, masalah keuangan, fasilitas maupun kurangnya ketersediaan sumber daya manusia mengingat yang bekerja di P2TPAKK Rekso Dyah Utami merupakan relawan.

\section{Penutup}

Berdasarkan hasil penelitian yang telah dibahas, maka dapat diambil kesimpulan bahwa tingginya angka kekerasan tindak kekerasan yang terjadi di kota Yogyakarta disebabkan oleh beberapa faktor seperti faktor ekonomi, faktor pendidikan, faktor sosial dan budaya patriarki yang masih lekat di indonesia. Implementasi kebijakan program yang dilaksanakan oleh Dinas Pemberdayaan perempuan dan perlindungan anak bersama dengan unit pelaksana teknis yaitu P2TPAKK Rekso Dyah Utami program perlindungan terdiri dari yaitu dari lima program yaitu 1) Program pencegahan kekekerasan, 2) Program 
Pelayanan pos pengaduan, konsultasi dan pendampingan, 3) Program Konseling dalam bidang kesehatan, psikologi, hukum, sosial dan kerukunan rumah tangga ,4) Program Layanan bantuan hukum, program rujukan, dan 5) Program Semi shelter, shelter dan pasca shelter. Penyelenggaraan program perlindungan sudah mencapai hasil yang cukup maksimal.

\section{Daftar Pustaka}

Antari Dila, Karjuni Dt. Maani, 2020, Implementasi Kebijakan Program Sosial Oleh Lembaga Konsultasi Kesejahteraan Keluarga (LK3) Dalam Menangani Kasus Kekerasan Dalam Rumah Tangga Di Lubuk Alung Kabupaten Padang Pariaman, Jurnal Mahasiswa Ilmu Administrasi Publik

Deimiati Susi, 2016, Kebijakan Penegakan Hukum Terhadap Perempuan Korban Kekerasan Dalam Rumah Tangga, Jurnal Litigasi

Jannah Fathul, Dkk, 2002, Kekerasan Terhadap Istri (Lkis:Yogyakarta)

Komnas perempuan.go.id diakses 30 mei 2021

Mohammad Taufik Makarao,Dkk, 2013, Hukum Perlindungan Anak Dan Penghapusan Kekerasan Dalam Rumah Tangga, (Rinek Cipta:Jakarta)

Nugroho Dwijowijoto Ryan, 2003, Kebijakan Publik Formulasi, Implementasi Dan Evaluasi (Jakarta:Eka Media Komputindo)

Nur Fadhilah, Sutiawati, 2020, Penanggulangan Tindak Pidana Kekerasan Dalam Rumah Tangga Di Kota Makassar, Jurnal Wawasan Yuridika.

Nur Rofi'ah, 2017, Kekerasan Dalam Rumah Tangga Dalam Perspektif Islam, Jurnal Ilmiah Agama Dan Sosial Budaya

Repjogja.republika.co.id diakses pada Minggu, 30 mei 2021

S Anshori Dadang Dkk, 1997, Membincangkan Feminism:Refleksi Muslimah Atas Peran Sosial Kaum Wanita (Bandung:Pustaka Hidayah)

Taufik Makarao, Mohammad , 2013, Dkk Hukum Perlindungan Anak D 
an Penghapusan Kekerasan Dalam Rumah Tangga, (Rinek Cipta:Jakarta)

UU N0. 23 Tahun 2004 Tentang Penghapusan Kekerasan Dalam Rumah Tangga, BAB 1 ketentuan umum, pasal 1 ayat

Wahab Solichin Abdul, Analisa Kebijakan Dari Formulasi Ke Implementasi Kebijakan Negara 